\title{
Correction to: The Interplay Between Aeschylus and Seneca in James Thomson's Agamemnon
}

\author{
Angelica Vedelago ${ }^{1}$ \\ Published online: 13 August 2018 \\ (C) Springer Nature B.V. 2018
}

\section{Correction to: Int Class Trad https://doi.org/10.1007/s12138-018-0462-1}

This article has been published with an erroneous phrase in the paragraph given in this correction. Please find herewith the correct version of the paragraph that should be regarded as final by the reader.

Thomson's Agamemnon represents the first extant attempt to adapt Aeschylus's play to the British stage; before it there had been a greater interest in Seneca's version of the play, with only a quite indirect engagement with the Aeschylean text in six or seven productions. ${ }^{19}$ Seneca is also a major source of Thomson's Agamemnon. As testified by both the catalogue of Thomson's books ${ }^{20}$ and the textual evidence analysed in the next paragraphs, Thomson read Seneca in John Studley's English translation in its second, 1581 edition. First published in 1566 by Thomas Colwell and then in 1581 by Thomas Newton in his collection The Tenne Tragedies of Seneca, Studley's translation remained the only English translation of Seneca's Agamemnon available until Watson Bradshaw's prose version (1902) and Ella Harris's verse rendition (1904). ${ }^{21}$ Thomson may have made use of the Latin text as well: the most recent edition available at that time dated back to 1685 , published in London by Johannes Redmayne with Thomas Farnaby's annotations, which were first printed in a 1613 edition. ${ }^{22}$

The original article can be found online at https://doi.org/10.1007/s12138-018-0462-1.

Angelica Vedelago

angelica.vedelago@phd.unipd.it

1 Dipartimento di Studi Linguistici e Letterari, Università degli Studi di Padova, Piazzetta G.

Folena 1, 35137 Padua, Italy 